\section{Where now with AIDS?}

\section{The time has come to stop being mesmerized by}

this new disease, and to do something about it.

IN society's lackadaisical defence (of itself) against the syndrome called AIDS, otherwise acquired immune deficiency syndrome, the article on page 277 of this issue is another landmark. Other equivalent landmarks will appear this week in other journais, Cell and Science. These three articles report the nucleotide sequences of particular isolates of the virus named HTLV III by Robert Gallo and his associates at the National Cancer Institute in the United States. Nature knows of a fourth viral sequence in the pipeline, just a few weeks behind, and there may well be others. But most readers of these articles will acknowledge that there is no obvious means by which any of them, or any combination of them taken together, will advance the treatment of a disease that, when full-blown, kills those affected with something like the certainty that summer is warmer than winter. There is a chance that the nucleotide sequences, or their comparison, will suggest some useful way of looking at the problem of treating this novel disease, but there is also a chance that they will do nothing of the kind. A bigger step was taken a few months ago, when it became clear beyond doubt that AIDS is caused, in part at least, by a virus that can be characterized in the laboratory and which can be recovered alive from body fluids as different as semen and saliva. Sequencing is merely better characterization, but in due course, as the permissible protein structures are defined, it will also no doubt have practical value for immunologists (people who, among other things, make vaccines).

The immediate interest of the three now-published nucleotide sequences will be in their comparison, and for a particular reason. Restriction enzyme mapping in several laboratories has already suggested apparently huge differences between the structure of one isolate of the virus and another. That discovery has seemed forbidding because it has suggested that different strains of the AIDS virus may differ from each other structurally, as do the viruses responsible for successive waves of influenza, a much more infectious entity. The defect in that conclusion is that restriction mapping, which consists of cutting pieces of DNA at specific sites, is ideally suited to telling small differences between largely similar genetic structures and that it may exaggerate differences between necessarily malleable genetic structures such as those of viruses. Nobody should be surprised if the differences between the genetic structures now published are of no biological significance, or are simple mistakes (what the electrical engineers would call noise). Equally, nobody should be surprised if the data suggest that the AIDS virus is so labile that the hope of making a universal vaccine is small.

So is it still an open question whether AIDS is a passing scare or a novel disease that has come to stay for good? In principle, yes; in practice, the weight of the evidence inclines to the opposing view that AIDS is a novel infectious disease that spreads only slowly, which for that reason has affected only small subcommunities. but which, because transmission is mostly sexual, will in due course put all of us at risk. It is particularly disturbing that AIDS has now been reported among female prostitutes in New York. Retrospectively, it is now known that AIDS has been established among men and women for at least six years.

That then, is the bad news; there is no obvious barrier except a vaccine (whose construction would be attended by the immunological complexities already recognized as well as by the problem of making the first vaccine against a retrovirus) to the general spread of the disease. The good news is that the timescale of the infectious process is long. Infection is clearly not overwhelmingly rapid. Not all those infected are certain to succumb. Certainly the analogue of the classical induction period is long, three or four years, perhaps. So there is a chance, even a good chance, that energy spent in the next few years on the understanding of the biology and the molecular biology of AIDS may literally help to avert the catastrophe as serious but more enduring than any of the horrid visions on which governments now lavish dollars in units of tens of millions. True, the questions provoked by AIDS are more taxing than those provoked by, say, acid rain. But in an age when battling against imagined cataclysm has become heroic, is not the case for worrying constructively about AIDS the more cogent?

\section{Other things not equal}

Dollars go up and pounds go down. The underlying reasons are linked with productiveness.

THE economists' standard way of disclaiming full responsibility for their conclusions, the English translation of the Latin ceteris paribus, has been widely used in the past few months, especially in connection with the United States budget deficit and its international ramifications. What the textbooks say is that a government that finances its public expenditure by borrowing what it cannot raise in taxes runs several risks. The most common is that the creation of domestic credit will stimulate inflation, a danger avoided in the United States largely because much of the borrowing has come from abroad. Another danger is that the need to borrow will keep interest rates high (because people must be tempted to part with their money. Another obvious risk for a government running a budget deficit (in excess of $\$ 200,000$ million this financial year) is that, other things being equal, the currency will depreciate as the supply of dollars overseas comes to exceed the willingness of people overseas to accumulate ever-larger piles of this commodity and its equivalents. But plainly, things are no longer equal. The currency that has fallen through the floor in the past few weeks is not the dollar but the pound sterling.

The economists' extenuating circumstances have dawned on people only slowly, but are in their own way also chilling. The willingness of people to lend money to a spendthrift government rests on the flexibility of the US economy in the past two years. The inflation rate has actually fallen (to 4 per cent a year) and industrial production has increased (by 6.4 per cent in a year, more quickly than in most industrial countries except Japan). Even so, the external trade deficit $(\$ 122,000$ million a year) is so high that it would keep most newly-inaugurated presidents awake at nights, while the money supply in the United States (up 10.3 per cent in a year) should have most people wondering how long overseas suppliers will be prepared to finance the unrequited import bill. The obvious danger is that the time will come when people's appetite for dollars is sated, when there will be a turnaround as uncomfortable for the United States as for others.

Britain, at the other end of the industrial spectrum, seems to have earned all the troubles that afflict the United States and those that still lie ahead of it. The British economy has proved to be less flexible than most, with the result that British exports to the United States have not risen as quickly as those of France and West Germany in response to the favourable exchange rate. Indeed, industrial production actually fell in Britain last year (partly because of a ten-month coal strike), earnings and as a consequence unemployment are both increasing, as is the money supply.

The morals of this tale of contrasts for the US government are clear - reduce the budget deficit, let interest rates decline still further and let the dollar decline modestly in value (as it would). So much is the price of avoiding instability on a grand scale. The recipe for the British government is harder to follow, if only because it has been tried in various forms for at least twenty years. The problem is to find some way of making the British economy more productive and more flexible. Successive governments of all stripes have aimed at these objectives by a variety of financial instruments, during the past decade by concentrating on inflation and the money supply. The present government has also tried, more openly than any since the Wilson Labour government of 1964 , to encourage high technology. The snag, now as then, is that the weaknesses of the British economy lie not so much in these long-term goals as in the need somehow to keep body and soul together in the short run. Structurally, middle technology has been virtually destroyed by the events of recent decades. So long as that remains the case, people will go on selling sterling. $\square$ 